\title{
Karakter morfologi, biologi, dan molekuler tiga isolat Helicoverpa armigera Nucleopolyhedrovirus (HearNPV) terhadap penggerek buah kapas Helicoverpa armigera Hubner (Lepidoptera: Noctuidae)
}

\author{
Morphology, biology, and molecular characteristics of three isolates of \\ Helicoverpa armigera Nucleopolyhedrovirus (HearNPV) \\ against cotton bollworm, Helicoverpa armigera Hubner \\ (Lepidoptera: Noctuidae)
}

\author{
Farriza Diyasti $^{{ }^{*}}$, Teguh Santoso ${ }^{2}$, R. Yayi Munara Kusumah ${ }^{2}$ \\ ${ }^{1}$ Direktorat Perlindungan Perkebunan \\ Jalan Harsono RM No. 3, Ragunan-Pasar Minggu, Jakarta Selatan 12550 \\ ${ }^{2}$ Departemen Proteksi Tanaman, Fakultas Pertanian, Institut Pertanian Bogor \\ Jalan Kamper, Kampus IPB Darmaga, Bogor 16680
}

(diterima November 2015, disetujui Maret 2016)

\begin{abstract}
ABSTRAK
Helicoverpa armigera Hubner (Lepidoptera: Noctuidae) merupakan hama penting pada kapas. Kehilangan hasil akibat serangan hama ini dapat mencapai $70 \%$. Pengendalian hama ini menggunakan nucleopolyhedrovirus (NPV) terbukti efektif di lapangan. Isolat NPV yang diperoleh dari spesies inang yang sama di lokasi geografis yang berbeda dapat menunjukkan variasi genetik dan perbedaan dalam biologinya. Penelitian ini bertujuan membandingkan karakteristik morfologi, biologi, dan molekuler ketiga isolat HearNPV yang berasal dari perkebunan kapas di Sulawesi Selatan, Jawa Tengah, dan Jawa Timur. Scanning electron microscope (SEM) digunakan untuk melihat karakter morfologi, sedangkan karakter biologi diamati dengan mencelupkan pipilan jagung muda pada tiap suspensi isolat dengan kerapatan $2,5 \times 10^{3}, 2,5 \times 10^{4}, 2,5 \times 10^{5}, 2,5 \times 10^{6}$, dan $2,5 \times 10^{7} \mathrm{POBs} / \mathrm{ml}$ serta kontrol menggunakan akuabides kemudian diberikan pada larva $H$. armigera instar-1. Analisis probit dilakukan untuk menghitung nilai LC dan LT. Uji molekuler menggunakan polymerase chain reaction (PCR) dengan bantuan primer gen lef- 8 . Hasil menunjukkan ketiga isolat memiliki bentuk dan ukuran polihedra yang tidak berbeda nyata dengan rerata diameter $0,86 \mu \mathrm{m}$. Pada $7 \mathrm{HSI}$, isolat HearNPV dari Jawa Timur menunjukkan persentase mortalitas tertinggi dengan nilai $\mathrm{LC}_{50}$ terendah, yaitu 6,38 POBs $/ \mathrm{ml}$, sedangkan nilai $\mathrm{LT}_{50}$ pada kerapatan $2,5 \times 10^{7} \mathrm{POBs} / \mathrm{ml}$ terendah ditunjukkan oleh isolat Jawa Timur dan Sulawesi Selatan, yaitu 2,7 HSI. Sementara itu, hasil sekuensing DNA dari ketiga isolat tersebut menunjukkan kemiripan yang tinggi (homologi 100\%).
\end{abstract}

Kata kunci: homologi, kerapatan, LC, mortalitas, $\mathrm{POB}$

\begin{abstract}
Helicoverpa armigera Hubner (Lepidoptera: Noctuidae) is one of the most important pests on cotton. Yield losses due to this pest can reach up to $70 \%$. Pest control using the NPV has been proven to be effective in the field. However NPV isolates from different geographical locations could be showed variation in genetic and their biology. The purpose of this study was to compare morphology, biology, and molecular characteristics between three HearNPV isolates from cotton
\end{abstract}

*Penulis korespondensi:Farriza Diyasti. Direktorat Perlindungan Perkebunan, Jalan Harsono RMNo.3, Ragunan-Pasar Minggu, Jakarta Selatan 12550 Tel: 021-7815380-4, Faks: 021-7815486, 7815586, Email: riza.diyasti@gmail.com. 
field in South Sulawesi, Central Java, and East Java. Scanning electron microscope (SEM) was used to look at morphological characters, whereas biological characters were observed by dipping shelled of young corn cob on each isolate suspension with a density of $2.5 \times 10^{3}, 2.5 \times 10^{4}, 2.5 \times 10^{5}, 2.5 \times$ $10^{6}, 2.5 \times 10^{7} \mathrm{POBs} / \mathrm{ml}$ and control then fed to the first instar larvae of $H$. armigera. Probit analysis was used to determine LC and LT. The molecular assay used polymerase chain reaction (PCR) with lef-8 gene. The results showed that the three isolates had the shape and size of polyhedra which was not significantly different with the mean diameter were $0.86 \mu \mathrm{m}$. The result showed that in 7 days post infection, HearNPV isolate from East Java was the most virulent isolates with the lowest $\mathrm{LC}_{50}$, which is $6.38 \mathrm{POBs} / \mathrm{ml}$, but lowest $\mathrm{LT}_{50}$ value in $2.5 \times 10^{7} \mathrm{POBs} / \mathrm{ml}$ were showed both from East Java and South Sulawesi, which are 2.7 days post infection. Meanwhile, the DNA sequencing of the three isolates showed a high similarity (100\% homology).

Key words: density, homology, LC, mortality, POB

\section{PENDAHULUAN}

Helicoverpa armigera Hubner (Lepidoptera: Noctuidae) merupakan salah satu hama utama kapas yang menjadi faktor pembatas produksi. Larva $H$. armigera merusak kapas dengan cara menggerek kuncup, bunga, dan buah kapas sehingga menyebabkan buah kapas tersebut tidak dapat berkembang dan gugur. Menurut Nasreen et al. (2004), satu individu larva $H$. armigera dapat menghabiskan 40-57\% kuncup, bunga, dan buah kapas dalam satu pohon selama fase hidupnya.

Pada skala lapangan, nucleopolyhedrovirus (NPV) dapat menekan kerusakan buah kapas sehingga mengurangi kehilangan hasil produksi kapas berbiji rerata 21,37\% (255,2 kg/ha) (Indrayani et al. 1998). Aplikasi NPV di laboratorium mampu menurunkan konsumsi makan $H$. armigera antara $25-50 \%$ dari berat kering pakan normal (Rustama \& Niloperbowo 2009). Efektivitas virus ini dipengaruhi oleh biologi inang, virulensi virus, dan ekologi virus (Trevor et al. 2005). Isolat Baculovirus yang diperoleh dari spesies yang sama di lokasi geografis yang berbeda sering menunjukkan variasi genetik dan perbedaan dalam biologinya (Cory et al. 2005). Penelitian terkait variasi strain Baculovirus di Indonesia telah dilakukan oleh Zelazny et al. (1977) yang menemukan adanya variasi genetik dan virulensi Baculovirus Oryctes rhinoceros (Coleoptera: Scarabaeidae) yang menyerang hama Oryctes rhinoceros Linnaeus pada sentra perkebunan kelapa di Indonesia. Berbagai variasi agroklimat yang beragam pada bentang wilayah yang cukup luas di Indonesia memungkinkan adanya variasi strain Baculovirus pada ekosistem lain, salah satunya kapas. Sentra kapas di Indonesia tersebar di Jawa Tengah, Jawa Timur, Sulawesi Selatan, Sulawesi Tenggara, Nusa
Tenggara Timur (NTT), Nusa Tenggara Barat (NTB), dan Bali.

Karakterisasi molekuler melalui teknik polymerase chain reaction (PCR) merupakan salah satu cara untuk mengidentifikasi suatu gen. Dengan menggunakan primer gen late expression factor 8 (lef-8) yang dapat mengamplifikasi DNA NPV pada Lepidoptera diharapkan dapat memberikan informasi karakter molekuler dari isolat HearNPV di Indonesia. Dengan demikian penelitian ini bertujuan untuk mengkaji perbedaan isolat Helicoverpa armigera NPV (HearNPV) dari beberapa wilayah sentra perkebunan kapas di Indonesia terkait karakter morfologi, biologi, dan molekulernya.

\section{BAHAN DAN METODE}

Penelitian dilaksanakan dari bulan September 2014-Agustus 2015. Sampel isolat HearNPV diperoleh dari perkebunan kapas di Kabupaten Gowa-Provinsi Sulawesi Selatan, Kabupaten Wonogiri, Provinsi Jawa Tengah dan Kabupaten Situbondo, Provinsi Jawa Timur. Uji bioesai dan pengolahan data dilakukan di Laboratorium Patologi Serangga, Departemen Proteksi Tanaman, Fakultas Pertanian, Institut Pertanian Bogor (IPB). Karakterisasi molekuler dilakukan di Laboratorium Virologi Tumbuhan, Departemen Proteksi Tanaman, Fakultas Pertanian, IPB. Pengamatan morfologi polihedra dilakukan di Laboratorium Zoologi, Lembaga Ilmu Pengetahuan Indonesia (LIPI)-Cibinong.

\section{Pemeliharaan serangga inang}

Larva $H$. armigera diperoleh dari pertanaman jagung di Kelurahan Ciparigi, Kecamatan Bogor 
Utara dan dipelihara secara individual dalam mangkok plastik berdiameter $5,5 \mathrm{~cm}$ dan tinggi 4,7 cm menggunakan pakan tongkol jagung muda. Pupa yang terbentuk dipindahkan ke wadah plastik berdiameter $34 \mathrm{~cm}$ dan tinggi $35 \mathrm{~cm}$ yang bagian dasarnya diisi dengan serbuk kayu. Bagian atas wadah ditutup dengan kain kasa sebagai tempat peletakan telur. Ngengat diberi pakan larutan madu $10 \%$ yang diresapkan pada kapas. Telur yang diletakkan pada kain kasa dipanen setiap hari. Setelah 24 jam, dilakukan sterilisasi terhadap permukaan telur menggunakan sodium hypoclorite $0,1 \%$. Larva yang diperoleh digunakan untuk tahap penelitian selanjutnya.

\section{Isolasi dan perbanyakan NPV}

Sampel cadaver ulat $H$. armigera yang menunjukkan gejala terserang NPV dari ketiga wilayah (Provinsi Sulawesi Selatan, Jawa Tengah, dan Jawa Timur) dikumpulkan kemudian dimurnikan di laboratorium. Cadaver digerus dengan mortar dalam larutan SDS 0,1\%, kemudian disaring menggunakan kain kasa berukuran 100 mesh. Filtrat dituang ke dalam tabung mikro $2 \mathrm{ml}$, kemudian disentrifugasi dengan kecepatan $2000 \mathrm{rpm}$ selama 1 menit. Pelet yang terbentuk dibuang, supernatan diambil dan disentrifugasi kembali dengan kecepatan $5000 \mathrm{rpm}$ selama 20 menit. Pelet yang terbentuk ditambahkan beberapa tetes akuabides (Cheng 1998). Pemurnian virus dilakukan dengan metode gradien sukrosa yang dibuat secara kontinu pada tabung mikro $2 \mathrm{ml}$ (Grzywacz et al. 2011). Selanjutnya, disentrifugasi dengan kecepatan 13000 rpm selama 99 menit. Pita putih yang terbentuk diambil dengan menggunakan pipet pasteur dan disuspensikan kembali dengan menambahkan beberapa tetes akuabides. Suspensi tersebut disentrifugasi kembali pada $7000 \mathrm{rpm}$ selama 20 menit. Endapan yang terbentuk diambil dan ditambahkan akuabides. Irisan jagung dicelupkan ke dalam suspensi tersebut untuk selanjutnya digunakan sebagai pakan larva instar-3 H. armigera. Ulat yang mati setelah mengonsumsi pakan tersebut, dikumpulkan dan diproses dengan metode yang sama untuk mendapatkan NPV yang diperlukan untuk tahap penelitian selanjutnya.

\section{Pengamatan morfologi polihedra isolat HearNPV}

Suspensi polihedra murni tiap isolat ditempatkan pada coverglass sebanyak satu lup inokulasi kemudian dikeringanginkan. Setelah kering, coverglass tersebut ditempelkan pada stub dengan menggunakan double tape carbon. Sampel kemudian dilapisi (coated) dengan emas menggunakan ion sputtering device (JEOL FINE COAT tipe JFC-1100 E) selama 4 menit dengan arus listrik sebesar $10 \mathrm{~A}$. Setelah pelapisan, sampel tersebut diamati dengan menggunakan SEM (Tipe JEOL JSM-5200) pada perbesaran 5000 kali.

\section{Bioesai NPV terhadap $H$. armigera}

Suspensi polihedra murni tiap isolat ditentukan kerapatannya dengan menggunakan haemacytometer. Kerapatan yang digunakan, yaitu $2,5 \times 10^{3}, 2,5 \times 10^{4}, 2,5 \times 10^{5}, 2,5 \times 10^{6}$, dan 2,5 x $10^{7} \mathrm{POBs} / \mathrm{ml}$. Pipilan jagung muda dicelupkan ke dalam masing-masing suspensi HearNPV dan diberikan pada larva $H$. armigera instar-1 sebanyak 20 individu tiap perlakuan. Perlakuan diulang sebanyak empat kali. Kontrol menggunakan pipilan jagung muda yang dicelupkan ke dalam akuabides.

\section{Ekstraksi dan amplifikasi DNA}

Polihedra yang telah dimurnikan menggunakan gradien sukrosa pada metode sebelumnya diresuspensi dengan larutan sodium karbonat $\left(\mathrm{Na}_{2} \mathrm{CO}_{3}, \mathrm{pH} 11\right)$, dan didiamkan pada suhu $37^{\circ} \mathrm{C}$ selama 30 menit, kemudian disentrifugasi kembali menggunakan tabung mikro $2 \mathrm{ml}$ pada $13000 \mathrm{rpm}$ selama 1 jam hingga terbentuk pelet yang merupakan kumpulan virion NPV. Virion dimurnikan dengan metode yang sama pada pemurnian polihedra (Cheng 1998), selanjutnya dilakukan ekstraksi DNA dengan menggunakan Viral nucleic acid extraction kit II (Geneaid VR050).

Amplifikasi menggunakan primer gen lef-8 dengan urutan oligonukleotida primer forward 5'-ATGAATTGCAAACTCTCCGCCCAG-3' dan reverse 3'-TCGACTGCAGACC-GCCGAAGA-5' (Kaur et al. 2014). Untuk amplifikasi tiap isolat HearNPV, sebanyak $2 \mu \mathrm{l}$ DNA hasil ekstraksi dicampur dengan reagen yang terdiri atas $8 \mu \mathrm{l}$ $\mathrm{ddH}_{2} \mathrm{O}, 12,5 \mu \mathrm{l}$ Taq DNA polymerase, masingmasing $1 \mu \mathrm{l}$ primer, $0,5 \mu \mathrm{MgCl}$ hingga volume akhir yang digunakan dalam amplifikasi sebanyak $25 \mu$ l. Amplifikasi dilakukan pada mesin PCR (gene amp system 9700). Satu siklus amplifikasi meliputi tiga tahapan utama, yaitu denaturasi $94{ }^{\circ} \mathrm{C}$ selama 1 menit, penempelan $61^{\circ} \mathrm{C}$ selama 1 menit, dan ekstensi $72^{\circ} \mathrm{C}$ selama 1 menit. Siklus diulangi 
sebanyak 35 kali. Proses elektroforesis dilakukan dengan memasukan $5 \mu$ DNA hasil amplifikasi ke dalam sumur gel agarose $1 \%$ yang direndam dalam larutan Tris Borate EDTA (TBE) kemudian dialiri dengan arus listrik 50 volt selama 50 menit. Selanjutnya, direndam dalam larutan ethidium bromida (EtBr) selama 30 menit. Visualisasi DNA dilakukan dengan cara meletakkan gel agarose pada UV-transiluminator.

\section{Analisis data}

Bioesai HearNPV. Pengamatan dilakukan terhadap mortalitas, tanda, serta gejala penyakit yang muncul tiap hari hingga seluruh larva uji mati. Persentase larva yang mati dihitung dan apabila terdapat mortalitas pada perlakuan kontrol (tidak lebih dari 20\%) maka mortalitas larva dikoreksi dengan formula Abbott (1925) dengan rumus sebagai berikut:

$$
\mathrm{P}=\frac{\mathrm{P}^{\prime}-\mathrm{C}}{\mathrm{P}^{\prime}-100} \times 100 \%, \text { dengan }
$$

P: mortalitas terkoreksi (\%); P': mortalitas hasil pengamatan pada setiap perlakuan HearNPV (\%); C: mortalitas pada kontrol (\%). Data diolah dengan menggunakan probit (Finney 1971) pada program statistical analysis system (SAS) untuk memperoleh nilai lethal concentration $\left(\mathrm{LC}_{50}\right.$ dan $\left.\mathrm{LC}_{90}\right)$, dan lethal time $\left(\mathrm{LT}_{50}\right.$ dan $\left.\mathrm{LT}_{90}\right)$.

Pengurutan DNA dan analisis filogeni. Pengurutan fragmen DNA hasil amplifikasi dilakukan oleh 1st BASE Singapura melalui PT. Genetica Science. Urutan nukleotida sampel dibandingkan dengan urutan nukleotida NPV lain yang telah dipublikasikan di situs National Centre for Biotechnology Information (NCBI) melalui program BLAST (Basic Local Alignment Search Tools). Data urutan nukleotida yang terpilih dianalisis menggunakan program penjajaran dan ClustalW dengan program Bioedit ver 7.1.7 untuk mengetahui homologi tiap sampel.

\section{HASIL}

\section{Bentuk dan ukuran polihedra}

Pengamatan menggunakan SEM menunjukkan bentuk polihedra pada isolat HearNPV Sulawesi Selatan, Jawa Tengah, dan Jawa Timur dengan ukuran yang tidak jauh berbeda. Polihedra isolat HearNPV Sulawesi Selatan berukuran $\mathrm{d}=0,84 \mu \mathrm{m}$, isolat HearNPV Jawa Tengah berukuran d $=0,92$ $\mu \mathrm{m}$, dan polihedra isolat HearNPV Jawa Timur berukuran $\mathrm{d}=0,87 \mu \mathrm{m}$ (Gambar 1).

\section{Bioesai NPV terhadap $H$. armigera}

Larva $H$. armigera yang mati akibat NPV menunjukkan gejala pergerakan melambat, aktivitas makan berkurang, dan cenderung berdiam diri pada bagian atas wadah percobaan (bagian tutup) yang pada akhirnya mati mengeluarkan cairan tubuh yang mengandung jutaan polihedra (Gambar 2). Uji bioesai menunjukkan bahwa pada kerapatan tinggi $\left(>2,5 \times 10^{5} \mathrm{POBs} / \mathrm{ml}\right)$, isolat HearNPV Sulawesi Selatan memiliki persentase mortalitas tertinggi terhadap $H$. armigera, sedangkan pada kerapatan rendah $\left(\leq 2,5 \times 10^{5} \mathrm{POBs} / \mathrm{ml}\right)$, isolat HearNPV Jawa Timur justru menunjukkan mortalitas $H$. armigera lebih tinggi dibandingkan dengan kedua isolat lainnya (Tabel 1). Semakin tinggi kerapatan maka semakin tinggi pula persentase mortalitas $H$. armigera.

Analisis probit memperlihatkan adanya perbedaan patogenisitas pada ketiga isolat HearNPV (Tabel 2). Pada 7 HSI, isolat HearNPV asal Jawa Timur menunjukkan nilai $\mathrm{LC}_{50}$ dan $\mathrm{LC}_{90}$

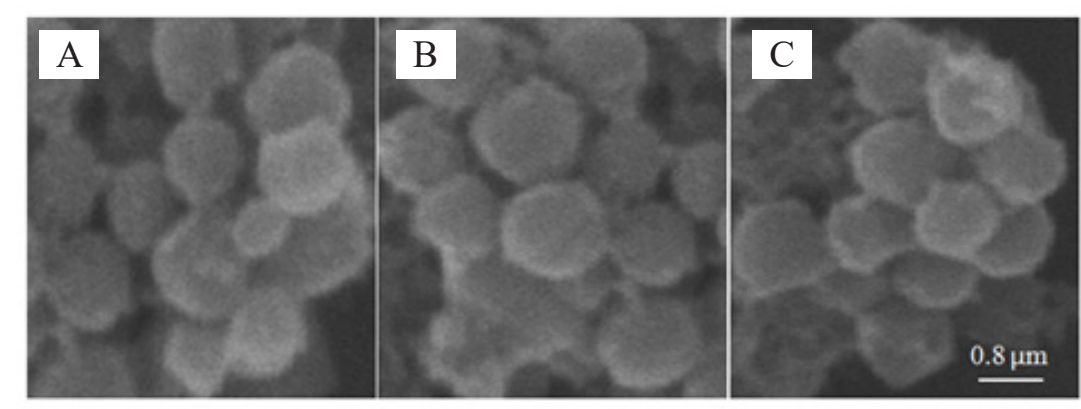

Gambar 1. Polihedra tiga isolat HearNPV melalui SEM 5000x. A: Sulawesi Selatan; B: Jawa Tengah; dan C: Jawa Timur. 


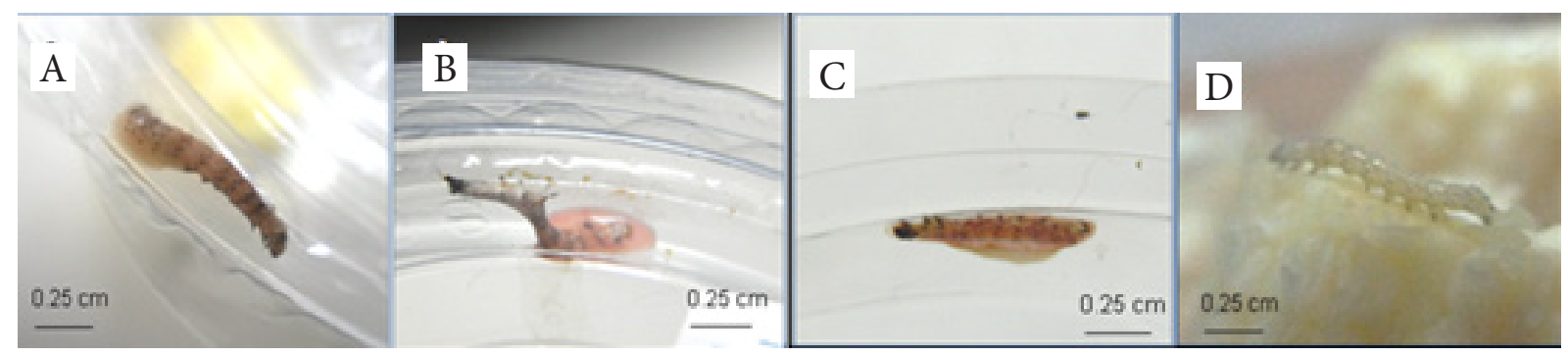

Gambar 2. Gejala larva Helicoverpa armigera terinfeksi oleh tiga isolat HearNPV pada 4 HSI. A: Sulawesi Selatan; B: Jawa Tengah; C: Jawa Timur; dan D: kontrol.

Tabel 1. Pengaruh tiga isolat HearNPV terhadap persentase mortalitas kumulatif larva Helicoverpa armigera

\begin{tabular}{|c|c|c|c|c|c|c|c|c|c|c|c|c|c|c|c|}
\hline \multirow{4}{*}{ HSI } & \multicolumn{15}{|c|}{ Mortalitas (\%) ${ }^{\mathrm{a}}$} \\
\hline & \multicolumn{15}{|c|}{ Kerapatan isolat HearNPV (POBs/ml) } \\
\hline & \multicolumn{3}{|c|}{$2,5 \times 10^{3}$} & \multicolumn{3}{|c|}{$2,5 \times 10^{4}$} & \multicolumn{3}{|c|}{$2,5 \times 10^{5}$} & \multicolumn{3}{|c|}{$2,5 \times 10^{6}$} & \multicolumn{3}{|c|}{$2,5 \times 10^{7}$} \\
\hline & SS & JTG & JTM & SS & JTG & JTM & SS & JTG & JTM & SS & JTG & JTM & $\mathrm{SS}$ & JTG & JTM \\
\hline 1 & 0,0 & 0,0 & 0,0 & 0,0 & 0,0 & 0,0 & 2,5 & 0,0 & 0,0 & 1,3 & 0,0 & 2,5 & 3,8 & 0,0 & 2,5 \\
\hline 2 & 0,0 & 5,1 & 12,5 & 2,5 & 6,3 & 18,8 & 12,5 & 7,6 & 22,5 & 32,5 & 14,0 & 31,3 & 41,3 & 12,7 & 31,3 \\
\hline 3 & 15,0 & 15,3 & 18,9 & 22,5 & 28,0 & 35,3 & 32,5 & 28,0 & 37,8 & 63,8 & 39,4 & 49,1 & 80,0 & 40,7 & 49,1 \\
\hline 4 & 37,7 & 29,3 & 52,3 & 52,8 & 39,5 & 57,4 & 62,8 & 53,6 & 72,7 & 77,9 & 57,4 & 75,3 & 85,3 & 70,2 & 75,3 \\
\hline 5 & 56,8 & 42,4 & 66,3 & 70,7 & 54,0 & 67,6 & 75,8 & 66,8 & 79,0 & 84,6 & 70,7 & 85,5 & 88,5 & 77,1 & 85,5 \\
\hline 6 & 63,6 & 54,0 & 69,9 & 73,8 & 63,0 & 71,2 & 80,2 & 74,6 & 80,4 & 85,3 & 78,4 & 90,6 & 89,2 & 83,5 & 90,6 \\
\hline 7 & 70,5 & 61,7 & 76,4 & 76,9 & 69,4 & 79,0 & 83,3 & 82,3 & 82,9 & 88,5 & 83,5 & 85,5 & 92,2 & 87,4 & 100 \\
\hline 8 & 75,6 & 68,1 & 80,3 & 83,3 & 74,6 & 85,5 & 85,3 & 86,1 & 85,5 & 89,1 & 86,1 & 100 & 100 & 100 & - \\
\hline 9 & 77,5 & 74,6 & 82,9 & 84,0 & 79,7 & 100 & 87,2 & 88,7 & 100 & 100 & 100 & - & - & - & - \\
\hline 10 & 81,4 & 81,0 & 84,2 & 85,3 & 84,8 & - & 100 & 100 & - & - & - & - & - & - & - \\
\hline 11 & 84,0 & 82,3 & 85,5 & 100 & 88,7 & - & - & - & - & - & - & - & - & - & - \\
\hline 12 & 89,3 & 83,5 & 100 & - & 100 & - & - & - & - & - & - & - & - & - & - \\
\hline 13 & 100 & 87,4 & - & - & - & - & - & - & - & - & - & - & - & - & - \\
\hline 14 & - & 90,0 & - & - & - & - & - & - & - & - & - & - & - & - & - \\
\hline 15 & - & 100 & - & - & - & - & - & - & - & - & - & - & - & - & - \\
\hline
\end{tabular}

${ }^{a}$ Rerata mortalitas terkoreksi (Abott 1925), SS: isolat HearNPV Sulawesi Selatan, JTG: isolat HearNPV Jawa Tengah, JTM: isolat HearNPV Jawa Timur

HSI: hari setelah inokulasi; -: menunjukkan mortalitas sudah mencapai 100\%.

terendah, yaitu pada kerapatan $6,36 \mathrm{POBs} / \mathrm{ml}$ dan $6,56 \times 10^{3} \mathrm{POBs} / \mathrm{ml}$, disusul oleh isolat HearNPV Sulawesi Selatan dengan kerapatan 9,80 POBs/ ml pada $\mathrm{LC}_{50}$ dan $3,89 \times 10^{4} \mathrm{POBs} / \mathrm{ml}$ pada $\mathrm{LC}_{90}$, selanjutnya isolat HearNPV Jawa Tengah dengan kerapatan $4,16 \times 10^{2} \mathrm{POBs} / \mathrm{ml}$ pada $\mathrm{LC}_{50}$ dan 4,04 x $10^{5} \mathrm{POBs} / \mathrm{ml}$ pada $\mathrm{LC}_{90}$. Pada kerapatan $2,5 \mathrm{x}$ $10^{7} \mathrm{POBs} / \mathrm{ml}$, isolat HearNPV Sulawesi Selatan dan Jawa Timur menunjukkan nilai $\mathrm{LT}_{50}$ dan $\mathrm{LT}_{90}$ yang tidak berbeda nyata (Tabel 2). Kedua isolat tersebut mampu mematikan 50\% populasi larva uji pada 2,7 HSI dan 90\% pada 4-5 HSI. Persamaan regresi yang terbentuk dari nilai virulensi isolat HearNPV Jawa Timur, yaitu y $=3,5 \mathrm{x}+77,5$ sehingga menghasilkan kurva yang sangat landai dengan nilai kemiringan (variabel X) 3,5 (Gambar 3). Hal ini mengindikasikan bahwa setiap terjadi perubahan nilai variabel bebas $\mathrm{X}(\log [\mathrm{K}])$ maka akan diikuti oleh perubahan variabel tidak bebas $\mathrm{Y}$ (probit mortalitas) sebesar 77,5.

\section{Karakter molekuler}

Amplifikasi DNA HearNPV dengan primer forward dan reverse gen lef- 8 menunjukkan hasil yang baik, terlihat dari terbentuknya pita DNA 1 , 2, dan 3. Total pita yang terlihat sesuai dengan target yang diinginkan, yaitu berukuran sekitar 789 pb (panjang basa) (Gambar 4). Berdasarkan 
Tabel 2. Nilai LC dan LT tiga isolat HearNPV terhadap mortalitas larva Helicoverpa armigera $(\alpha=5 \%)$

\begin{tabular}{lcccc}
\hline \multirow{2}{*}{ Isolat Hear $\mathrm{NPV}$} & \multicolumn{2}{c}{ Virulensi pada $7 \mathrm{HSI}(\mathrm{POBs} / \mathrm{ml})$} & \multicolumn{2}{c}{$\begin{array}{c}\text { Kecepatan membunuh pada 2,5 } \times 10^{7} \\
\text { POBs } / \mathrm{ml}(\mathrm{HSI})\end{array}$} \\
\cline { 2 - 5 } & $\mathrm{LC}_{50}$ & $\mathrm{LC}_{90}$ & $\mathrm{LT}_{50}$ & $\mathrm{LT}_{90}$ \\
\hline Sulawesi Selatan & 9,8 & $3,9 \times 10^{4}$ & 2,7 & 4,4 \\
& $\left(2,82-5,37 \times 10^{2}\right)$ & $\left(1,55 \times 10^{4}-1,17 \times 10^{5}\right)$ & $(2,32-3,05)$ & $(3,85-5,24)$ \\
Jawa Tengah & $4,2 \times 10^{2}$ & $4,0 \times 10^{5}$ & 3,2 & 6,0 \\
& $\left(3,98 \times 10-1,62 \times 10^{3}\right)$ & $\left(1,28 \times 10^{5}-1,55 \times 10^{6}\right)$ & $(2,99-3,42)$ & $(5,59-6,45)$ \\
Jawa Timur & 6,4 & $6,6 \times 10^{3}$ & 2,7 & 4,8 \\
& $\left(6,92 \times 10^{-4}-1,26 \times 10^{2}\right)$ & $7,76 \times 10^{2}-2,29 \times 10^{4}$ & $(2,51-2,88)$ & $(4,45-5,20)$ \\
\hline
\end{tabular}

HSI: hari setelah inokulasi

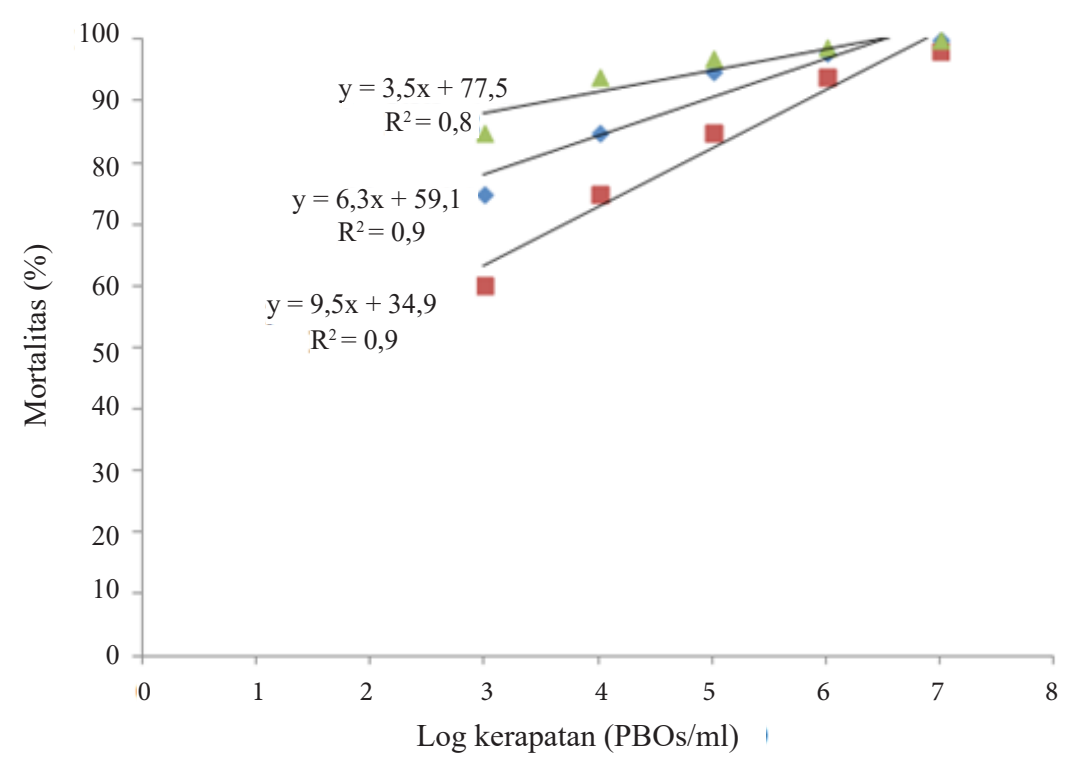

Gambar 3. Mortalitas probit (lethal concentration) tiga isolat HearNPV terhadap Helicoverpa armigera pada 7 HSI. $\bullet$ : Sulawesi Selatan; $₫:$ Jawa tengah; $\Delta$ : Jawa Timur.

analisis pensejajaran, isolat HearNPV Sulawesi Selatan, Jawa Tengah, dan Jawa Timur memiliki daerah consensus yang sama sehingga mengindikasikan bahwa ketiganya merupakan strain HearNPV yang sama dengan homologi $100 \%$ (Tabel 3). Selain itu, ketiga isolat HearNPV asal Indonesia ini menunjukkan kekerabatan tinggi dengan isolat H. zea NPV asal Brazil (No. aksesi Genbank: KM596835.1), dan H. armigera NPV Spanyol (No. aksesi Genbank: KJ701033.1). Homologi yang tinggi juga ditunjukkan oleh isolat pembanding lainnya, yaitu HearNPV India (No. aksesi Genbank: FJ157286.1), Nigeria (No. aksesi Genbank: AP010907.1), Australia (No. aksesi Genbank: JN584482.1), dan Cina (No. aksesi Genbank: AF271059.2).

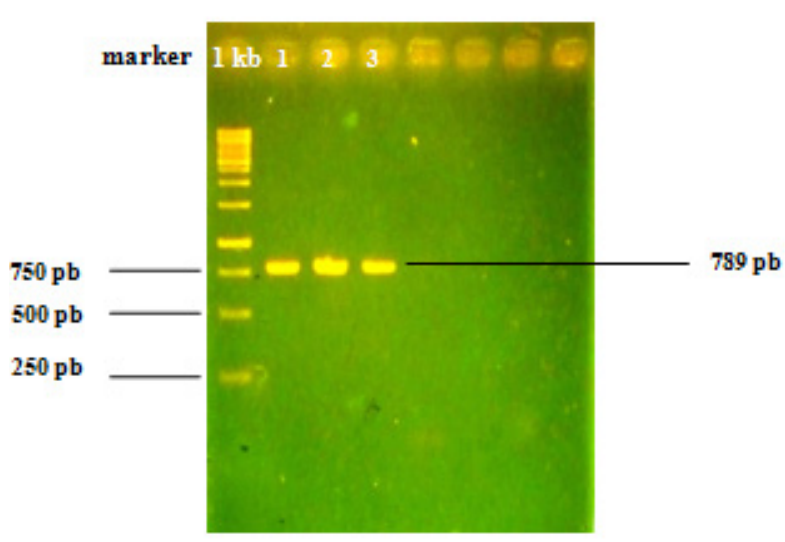

Gambar 4. Hasil visualisasi DNA HearNPV. 1: Sulawesi Selatan; 2: Jawa Tengah; dan 3: Jawa Timur. Menggunakan primer gen lef-8. 
Tabel 3. Homologi HearNPV Sulawesi Selatan, Jawa Tengah, dan Jawa Timur gen lef-8 dengan sampel dari GenBank

\begin{tabular}{llllllllll}
\hline & 1 & 2 & 3 & 4 & 5 & 6 & 7 & 8 & 9 \\
\hline 1 & ID & & & & & & & & \\
2 & 1 & ID & & & & & & & \\
3 & 1 & 1 & ID & & & & & & \\
4 & 1 & 1 & 1 & ID & & & & & \\
5 & 1 & 1 & 1 & 1 & ID & & & & \\
6 & 0,987 & 0,87 & 0,987 & 0,987 & 0,987 & ID & & & \\
7 & 0,989 & 0,989 & 0,989 & 0,989 & 0,989 & 0,992 & ID & & \\
8 & 0,987 & 0,987 & 0,987 & 0,987 & 0,987 & 1 & 0,992 & ID & \\
9 & 0,984 & 0,984 & 0,984 & 0,984 & 0,984 & 0,982 & 0,979 & 0,982 & ID \\
\hline
\end{tabular}

1: HearNPV Sulawesi Selatan; 2: HearNPV Jawa Tengah; 3: HearNPV Jawa Timur; 4: HearNPV Spanyol; 5: HezeNPV Brazil; 6: HearNPV Australia; 7: HearNPV Nigeria; 8: HearNPV Cina; 9: HearNPV India; ID : Identity.

\section{PEMBAHASAN}

Pada pengamatan dengan menggunakan SEM, ukuran polihedra dari ketiga isolat HearNPV cenderung sama, tidak menunjukkan perbedaan yang nyata. Cheng (1998) mengemukakan ukuran dan bentuk polihedra (OB) cukup bervariasi bergantung pada spesies. Penelitian yang dilakukan Sudhakar \& Mathavan (1999) menunjukkan ukuran polihedra NPV asal India berkisar $0,6-2,3 \mu \mathrm{m}$ yang sebagian besar berbentuk bulat, namun untuk menggambarkan perbedaan mendalam dapat melalui pengirisan melintang (cross-section) pada polihedra agar diketahui jumlah partikel virus dalam satu polihedra. Hal ini diperkuat oleh Guo et al. (2006) yang menyatakan bahwa patogenisitas dan kecepatan membunuh isolat HearNPV terhadap larva $H$. armigera tidak berkorelasi dengan bentuk dan ukuran polihedra melainkan berpengaruh terhadap produksi occlusion derived virus (ODV). Uji bioesai menunjukkan bahwa dengan meningkatnya kerapatan HearNPV yang diinokulasikan pada larva instar pertama $H$. armigera maka semakin meningkat pula jumlah larva uji yang mati. Pada kerapatan rendah $(2,5$ x $\left.10^{3} \mathrm{POBs} / \mathrm{ml}\right)$, ketiga isolat mampu mematikan seluruh populasi larva uji setelah $10 \mathrm{HSI}$. Pada kerapatan tinggi $\left(2,5 \times 10^{7} \mathrm{POBs} / \mathrm{ml}\right)$, ketiga isolat mampu mematikan seluruh populasi larva uji pada 7 HSI. Efektifitas penggunaan HearNPV untuk mengendalikan hama $H$. armigera dipengaruhi oleh beberapa faktor seperti kerapatan virus, pengaruh radiasi, instar ulat yang diserang dan isolat virus (Asri et al 2003). Percobaan yang dilakukan oleh Gundannavar \& Lingappa (2004) pada isolat HearNPV dengan kerapatan $10^{6} \mathrm{POBs} /$ $\mathrm{ml}$ dapat menyebabkan mortalitas $H$. armigera dari $50-100 \%$ dalam kurun waktu 5-8 HSI. Pada kerapatan yang lebih rendah, yaitu $10^{3} \mathrm{POBs} / \mathrm{ml}$, mortalitas larva uji mencapai $66,67 \%$ pada $10 \mathrm{HSI}$. Kerapatan infektif untuk NPV bervariasi terhadap usia larva, semakin tua larva uji yang digunakan maka kerapatan yang diperlukan juga semakin meningkat. Menurut Pourmirza (2000), tidak ada perbedaan kerentanan yang signifikan antar instar larva dalam mengekspresikan polihedra/mg dalam masing-masing berat larva. Dengan demikian, penggunaan instar-1 (neonate) sebagai larva uji dapat dilakukan dengan pertimbangan kebugaran larva yang seragam mudah diperoleh, jumlah larva uji yang dibutuhkan cukup besar, dan kemudahan dalam memperoleh larva uji bebas kontaminan cukup praktis dilakukan melalui sterilisasi permukaan telur (Grzywacz et al. 2011), serta efisiensi waktu dan ekonomi (Gunning 2011).

Perbedaan isolat NPV diduga memengaruhi mekanisme kerja virus tersebut dalam mematikan inangnya. Menurut Grzywacz et al. (2011), virion yang terlepas melewati membran peritrofik pada saluran pencernaan dan melebur dengan mikrovili pada sel epitel kolumnar. Virion mengandung nukleokapsid yang di dalamnya terdapat DNA, akan masuk ke dalam sitoplasma dan menuju inti sel melalui pori pada inti sel. Hal ini merupakan 
siklus replikasi awal dari virus. Nukleokapsid beristirahat dan DNA mulai bereplikasi. Selama kurang lebih satu jam setelah infeksi, virus mulai bereplikasi. Nukleus mengalami pembengkakan pada delapan jam setelah infeksi. Setelah itu, progeni virus membentuk tunas disebut peplomer (budded virus) untuk bermigrasi di luar sel. Produksi polihedra ini biasanya memakan waktu 48 jam. Pada tahap ini siklus primer telah selesai dan selanjutnya memulai siklus kedua dengan menginfeksi jaringan tubuh lainnya. Gejala infeksi virus pada serangga akan menunjukkan adanya perubahan bertingkat dalam warna integumen yang semakin bertambah gelap dan tampak berminyak (Toprak et al. 2005). Kutikula larva yang terinfeksi NPV menipis dan menjadi rapuh akibat kinerja gen cathepsin dan enzim kitinase yang terdapat dalam genom Baculovirus. Adapun perkembangan fase larva yang terinfeksi NPV cenderung lebih lamban dan lama. Hal ini disebabkan oleh adanya fungsi gen ecdysteroidglucosyl transferase (egt) yang dimiliki oleh NPV (Etebari et al. 2007) yang berfungsi menonaktifkan hormon ecdysteroid serangga inang sehingga stadia larva dari serangga yang terinfeksi virus akan semakin panjang (Koul \& Dhaliwal 2002).

Derajat patogenisitas (virulensi) virus ini didasarkan pada kemampuan virus membunuh organisme sasaran dalam jumlah yang besar dan waktu yang singkat. Nilai LC dan LT yang rendah menunjukkan sifat patogenisitas yang tinggi (Finney 1971). Isolat HearNPV Jawa Timur mampu mematikan larva uji dalam jumlah cukup besar pada kerapatan minimum. Selanjutnya, disusul oleh isolat HearNPV Sulawesi Selatan, kemudian Jawa Tengah. Brown (1982) menyatakan bahwa virus yang berasal dari spesies inang yang sama, namun dari lokasi geografis yang berbeda menunjukkan variasi dalam virulensi, karakter biologi, dan perbedaan dalam susunan DNA.

Pengamatan karakter molekuler ketiga isolat ini dengan PCR menggunakan gen lef-8 menunjukkan isolat HearNPV Sulawesi Selatan, Jawa Tengah, dan Jawa Timur pada satu strain yang sama dengan tingkat homologi $100 \%$. Li et al. (2009) mengemukakan bahwa suatu spesies dikatakan identik apabila persentase kemiripan $>73 \%$. Gen lef- 8 mampu mengamplifikasi DNA NPV Lepidoptera (Acharya \& Gopinathan 2002). Gen lef-8 merupakan gen ekspresi pada NPV yang cukup stabil mengkode subunit DNA dan menempel langsung pada RNA polimerase virus secara spesifik (Herniou et al. 2003). Patogenisitas virus merupakan proses yang kompleks dan melibatkan aksi dari beberapa gen (Griffiths et al. 1999). Sekuen polihedrin baik nukleotida maupun asam amino digunakan untuk mengidentifikasi kekerabatan dan asal-usul variasi NPV. Sejalan dengan ini, sekuen lef- 8 juga memiliki fungsi yang sama dengan sekuen polihedrin. Protein polihedrin dan gen lef- 8 mengatur struktur dan fungsi protein pada Baculovirus (Kaur et al. 2014). Beberapa kelompok strain dengan nilai kemiripan yang tinggi, akan dicatat berdasarkan posisi relatif nukleotida pada sekuen tiap individu sehingga akan menunjukkan kesamaan unit dasar pada genom bukan pada pola situs pemotongan. Ada beberapa susunan nukleotida yang terlihat berbeda namun memiliki fungsi gen yang sama, dengan adanya gen lef- 8 akan memadatkan fungsi tersebut dengan menetralkannya berdasarkan degenerasi penggunaan kodon. Isolat HearNPV Sulawesi Selatan, Jawa Tengah, dan Jawa Timur (Indonesia) pada penelitian ini menunjukkan hubungan kekerabatan yang cukup dekat dengan isolat Helicoverpa NPV dari Brazil, Spanyol, Cina, Nigeria, India, dan Australia. Hal ini diduga karena keenam negara tersebut juga merupakan negara penghasil kapas cukup besar di dunia sehingga adanya kemungkinan sejarah penyebaran dan penggunaan strain HearNPV yang berasal dari satu wilayah yang sama. Adapun variasi petogenisitas di antara tiga isolat HearNPV diduga karena perbedaan iklim pada wilayah tersebut. Peningkatan temperatur suatu wilayah dapat menghasilkan strain virus dengan virulensi tinggi, namun berkorelasi negatif dengan kelembaban (Gopali \& Lingappa 2001).

\section{KESIMPULAN}

Isolat HearNPV dari Jawa Timur menunjukkan persentase mortalitas tertinggi dengan nilai $\mathrm{LC}_{50}$ dan $\mathrm{LC}_{90}$ terendah, yaitu $6,38 \mathrm{POBs} / \mathrm{ml}$ dan $6,56 \times 10^{3} \mathrm{POBs} / \mathrm{ml}$, dibandingkan dengan isolat HearNPV Sulawesi Selatan dan Jawa Tengah. Perbedaan patogenisitas ini tidak berkorelasi dengan bentuk dan ukuran polihedra NPV. Berdasarkan analisis urutan DNA, ketiga 
isolat HearNPV ini merupakan strain virus yang sama dan memiliki hubungan kekerabatan yang dekat dengan isolat HezeNPV Brazil, HearNPV Spanyol, Cina, Nigeria, India, dan Australia.

\section{DAFTAR PUSTAKA}

Abbott WS. 1925. A method of computing the effectiveness of an insecticide. Journal of Economic Entomology 18:265-267. doi: http:// dx.doi.org/10.1093/jee/18.2.265a.

Asri MT, Isnawati, Hidayat MT. 2003. Konsentrasi Virus $H a \mathrm{NPV}$ isolat Yogyakarta yang efektif untuk mengendalikan ulat Helicoverpa armigera. Jurnal Pendidikan Matematika dan Sains 3:150-154.

Acharya A, Gopinathan KP. 2002. Characterization of late gene expression factors $l e f-9$ and $l e f-8$ from Bombyx mori nucleopolyhedrovirus. Journal of General Virology 83:2015-2023. doi: http:// dx.doi.org/10.1099/0022-1317-83-8-2015.

Brown DA. 1982. Two naturally occurring nuclear polyhedrosis variant of Neodiprion sertifer Geoffr. (Hymenoptera: Diprionidae). Applied and Environmental Microbiology 43:65-69.

Cheng XW, Carner GR. 2000. Characterization of a single-nucleocapsid nucleopolyhedrovirus of Thysanoplusia orichalcea L. (Lepidoptera: Noctuidae) from Indonesia. Journal of Invertebrate Pathology 75:279-87. doi: http:// dx.doi.org/10.1006/jipa.2000.4933.

Cory JS, Green BM, Paul RK, Hunter-Fujita F. 2005. Genotypic and phenotypic diversity of a Baculovirus population within an individual insect host. Journal of Invertebrate Pathology 89:101-111. doi: http://dx.doi.org/10.1016/j. jip.2005.03.008.

Etebari K, Matindoost L, Mirhoseini SZ, Turnbull MW. 2007. The effect of BmNPV infection on protein metabolism in silkworm (Bombyx mori) larvae. Invertebrate Survival Journal 4:13-17.

Finney DJ. 1971. Probit Analysis. London: Cambridge Univ Press.

Gopali JB, Lingappa S. 2001. Selection of virulent strain of NPV against Helicoverpa armigera in pigeon pea ecosystem. Karnataka Journal of Agricultural Sciences 14:1067-1071.

Griffiths CM, Barnett AL, Ayres MD, Windass J, King LA, Possee RD. 1999. In vitro host range of Autographa californica nucleopolyhedrovirus recombinants lacking functional. Journal of General Virology 80:1055-1066. doi: http:// dx.doi.org/10.1099/0022-1317-80-4-1055.
Grzywacz D, Rabindra RJ, Brown M, Jones KA, Parnell M. 2011. The Helicoverpa armigera NPV Manual Production. FAO. Tersedia pada: http:// www.fao.org/docs/eims/upload/agrotech/2011/ HearNPVmanual-pt1.pdf. [diakses 2014 Sep. 5].

Gundannavar KP, Lingappa Giraddi RS. 2004. Studi of interaction between virus and entomofungal pathogens against Helicoverpa armigera Hubner. Karnataka Journal of Agricultural Sciences 17:594-596.

Gunning RV. 2011. Measuring insecticide resistance. In: Zalucki MP (Eds.), Heliothis: Research Methods and Prospects. pp. 151-160. New York: Springer Verlag New York Inc.

Guo ZJ, Ge JQ, Wang D, Shao YM, Tang QY, Zhang CX. 2006. Biological comparison of two genotypes of Helicoverpa armigera single-nucleocapsid nucleopolyhedrosisvirus. Biological Control 51:809-820. doi: http:// dx.doi.org/10.1007/s10526-006-9008-6.

Herniou EA, Olezewski JA, Cory JS. 2003. The genome sequence and evolution of baculoviruses. Annual Review of Entomology 48:211-234. doi: http://dx.doi.org/10.1146/ annurev.ento.48.091801.112756.

Indrayani IGAA, Winarno D, Soebandrijo. 1998. Efektivitas NPV dengan berbagai bahan pembawa terhadap Spodoptera litura F. dan Helicoverpa armigera Huber pada kapas. Jurnal Littri 4:1-7.

Kaur B, Gupta VK, Jindal V. 2014. Molecular filogenetic analysis of Indian strains of Helicoverpa armigera nucleopolyhedrovirus (HearNPV). Indian Journal of Biotechnology 13:186-194.

Koul O, Dhaliwal GS. 2002. Microbial Biopesticides. London: Taylor and Francis. doi: http://dx.doi. org/10.4324/9780203303078.

Li YP, Yang BS, Wang H, Zia RX, Wang L, Zhang ZH, Qil L, Liu YQ. 2009. Mitochondrial DNA analysis reveals a low nucleotide diversity of Caligula japonica in China. African Journal of Biotechnology 8:2707-2712.

Nasreen A, Cheema GM, Fareed S, Saleem MA. 2004. Resistance of different cotton cultivars to chewing insect pests. Pakistan Entomologist 26:81-85.

Pourmirza AA. 2000. Relationship between nuclearpolihedrosis virus susceptibility and larval weight in Heliothis armigera. Journal of Agricultural Science and Technology 2:291-298.

Rustama MM, Niloperbowo W. 2009. Pengaruh dosis Helicoverpa armigera Nucleopolyherdosis VIRUS ( $H a \mathrm{NPV})$ terhadap konsumsi makan, 
berat badan, dan berat pupa Helicoverpa armigera (Huber). Tersedia di: http:// repository.unpad.ac.id/4015/1/pengaruh_dosis helicoverpa_armigera_nuclear_polyhedrosis virus.pdf. [diunduh 2015 Sept 5].

Sudhakar S, Mathavan S. 1999. Electron microscopical studies and restriction analysis of Helicoverpa armigera nuclear polyhedrosis virus. Journal of Biosciences 24:361-370. doi: http://dx.doi.org/10.1007/BF02941250.
Toprak U, Batram S, Gurkan MO. 2005. Baculoviruses as biocontrol agents, do they have a future in Turkey?. African Journal of Microbiology pp. 1-8.

Trevor AJ, Allan M, Crawford, Travis R, Glare. 2005. Oryctes virus (Baculovirus oryctes). Journal of Invertebrate Pathology 89:91-94.

Zelazny B. 1977. Occurrence of the Baculovirus disease of the coconut palm rhinoceros beetle in the Philippines and in Indonesia. FAO Plant Protection Bulletin 25:73-77. 